\title{
Calendar of Events 2018
}

Overview

March 7-9, 2018

$15^{\text {th }}$ Annual ENETS Conference

Barcelona, Spain

March 17-20, 2018

ENDO 2018

Chicago, Illinois

April 13-14, 2018

Kontrowersje NEN

Katowice, Poland

April 20-24, 2018

$12^{\text {th }}$ World Congress of The World Federation

of Nuclear Medicine and Biology

Melbourne, Australia

\section{May 19-22, 2018}

$20^{\text {th }}$ European Congress of Endocrinology (ECE 2018)

Barcelona, Spain

\section{May 23-26, 2018}

XVI Naukowy Zjazd Polskiego Towarzystwa

Medycyny Nuklearnej

Szczecin, Poland
September 15-18, 2018

$41^{\text {st }}$ Annual Meeting of the European

Thyroid Association (ETA)

Newcastle, England

October 03-07, 2018

$88^{\text {th }}$ Annual Meeting of the American

Thyroid Association

Washington, DC

\section{October 13-17, 2018}

$31^{\text {st }}$ Annual Congress of the European Association of Nuclear Medicine (EANM)

Düsseldorf, Germany

October 17-20, 2018

$18^{\text {th }}$ Congress of the European

Neuroendocrine Association (ENEA)

Wroclaw, Poland 